\title{
VIRPI LUOMA
}

\section{The Enlightenment A century on its way to multiculturalism}

$\mathrm{T}$

his essay brings out the cultural encounters which characterise the Enlightenment and the contemporary situation. The Enlightenment was an era when cultural encounters were on the rise, but it was also a time when racist attitudes were acceptable. This essay suggests, from a young history student's point of view, how we should deal with contemporary racism and cultural encounters and how can we critically view the racial attitudes which were characteristic of the early modern period.

CURIOSITY IS PART OF HUMAN NATURe. Those who lived centuries ago were also interested in foreign cultures, foreign peoples, and their own position on the world map. During the Age of Enlightenment several explorers, merchants and missionaries travelled further and further beyond the boundaries of the known world. Even though there had been expeditions and trade with foreign peoples earlier, during the eighteenth century strange cultures became more familiar than before. More and more people came into contact with an unfamiliar culture either face-to-face, or through books and exotic goods or materials. Travellers wrote descriptions of their journeys, and these were discussed by both the gentry and the peasantry. In addition to actual descriptions, accounts of completely fictitious travels soon appeared, and it was not always easy to recognise the difference between truth and tale.

In the Age of Enlightenment, intercultural encounters often meant defending one's own right to exist-be it by means of the pen or the sword. This was how people attempted to justify and define their emerging Western identity and culture. Depending on the viewpoint, other cultures were used either to criticise or praise European values and customs. To the modern reader, the argumentation seems very colourful. To give an example, the Abbot Guillaume Thomas Raynal (1713-96) considered it rather sensible to think that weather conditions had an impact on a person's character and nature. The hot climate of Arabia made people creative to some extent, but yet it also made them lazy. The cool climate of Europe, however, guaranteed good taste, and an industrious nature.

Reading the writings of the Enlightenment from a modern perspective, it is easy to be taken aback by their racist attitudes. Nowadays we know that separate human races do not exist, and that appearance does not give an indication other personal qualities. Nevertheless, we have not been able to lose that feeling of threat and fear which may easily surface during encounters with people from foreign cultures. In the Age of Enlightenment people were afraid that Islam might conquer Europe, while today in addition to Muslims we fear the Chinese, who are reportedly coming to steal our jobs. Just like Edward Gibbon, we consider non-European peoples to be a threat to our own existence. In order to justify contemporary racism, people use as their excuses 'sensible' immigration policies, globalisation, or the omnipotence of market forces.

In the views of Montesquieu and Voltaire, tolerance gains strength through the policies of a free market economy and trade. In fact, growing world trade has made us even more dependent on each other, which in turn has increased tolerance. Nevertheless the free market economy has led to even greater exploitation and to the despicable pursuit of selfish interests, in which the end justifies the means. Mere tolerance is not enough any more. We cannot 
be satisfied with begrudgingly enduring the presence of other cultures. Instead, what is needed is more profound understanding and equality.

Culture is in essence about knowing oneself and others. Even though in the eighteenth century one would travel halfway across the world fuelled by a thirst for knowledge, the journey was also fuelled by a desire to discover one's own self. Many of our ways of explaining strange cultures actually reveal more of our own culture than of that which is thought to be unfamiliar. Hence, we should first strive to know ourselves and understand our own culture, before we are able to understand others.

The rate of intercultural encounters began to rise during the Enlightenment, and it has been doing so increasingly ever since. Nowadays foreign cultures are constantly present, as the internet and other media transfer messages and images from all corners of the world. And yet we are still not able to tell truth from tale. One can spread racism on the internet anonymously and with alarming efficiency. I think that if we want to learn to encounter other cultures, now is the time to start paying attention to our thinking and reading skills. Today it is more and more important that people are able to view what they have seen and read with a critical eye. One has to learn to question ideas, and to realise what intentions a message might have, and how its contents are contingent upon on the motives and the background of its author.

How then could thinking and questioning be taught? How may we reach a more profound understanding of ourselves and other cultures? In my opinion the answer lies in the humanities. History, philosophy, comparative religion and other branches of the field develop intellect, world-views and identity. At the same time, one learns to question and to give reasons for one's own opinions. Instead of schools constantly cutting back on teaching the humanities, the discipline should be increased substantially. To use myself as an example, studying history has taught me to think for myself and to question. This has been an aid during intercultural encounters, for I attempt to question my own fears, my prejudices and the superiority of my culture, which in turn makes it easier to have an open mind towards new cultures. Through life experiences I have also come to know myself, my weaknesses and my strengths better. If you do not expect superhuman perfection from yourself, you automatically give others the chance to be themselves, too. To sum up, empathy and intellect are the necessary ingredients for greater tolerance and understanding.
I consider the greatest legacy of the Enlightenment to be the development of thought. The critical and independent thinking that developed during that era helps us to understand ourselves and others better. Still, it takes time to understand other cultures and to increase one's own tolerance towards them. It also requires patience, and what is perhaps the most important thing, an apt person to share the discussion.

\section{Translated from Finnish by Aleksi Mäkilähde.}

Virpi Luoma, BA, is a student of General History at Turku University. She is interested in Orientalism, cultural encounters and the Enlightenment. E-mail: vmluom(at)utu.fi.

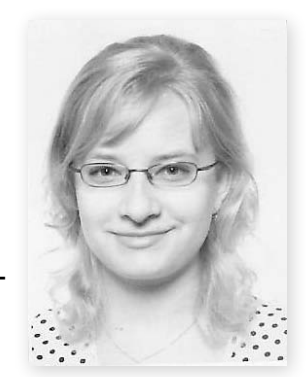

\section{Literature}

Luoma, Virpi 2011. 'Kulttuurien kohtaamiset 1700-luvun kirjoituksissa.' In: Janne Tunturi (ed.), Valon ja pimeyden kirjoituksia. Esseitä valistuskirjallisuuden klassikoista. 19-23. Turku: Aboagora. 